\title{
How to Become Experienced? The Practice of Novice Lecturer Professional Development at A Public University
}

\author{
Yu Hong, Arnida Abdullah, \\ Soaib Asimiran and Mohd Mokhtar Muhamad \\ Universiti Putra Malaysia, Serdang, Selangor, Malaysia \\ https:/ / orcid.org/0000-0002-8158-0494 \\ https:/ / orcid.org/0000-0001-6593-7310 \\ https:/ / orcid.org/0000-0002-2981-9509 \\ https://orcid.org/0000-0001-5376-6016
}

\begin{abstract}
Novice lecturer professional development is regarded as a continuous process that begins during pre-service lecturer training and continues throughout the academic career. It is focused on enabling and empowering lecturers by improving their professional confidence, teaching skills, and classroom management. The purpose of this paper is to explore the professional development practices of novice lecturers and to comprehend their situation and feelings about these practices at a public university in China. Using a qualitative case study, five novice lecturers were selected to participate in this study. Relevant programs and activities on professional development are analyzed. Semistructured interviews were conducted to explore the perceptions of novice lecturers. Another data collection method was documentation. The findings indicate that the professional development practices of novice lecturers in this selected university were done by organizing lecturer teaching competitions, teaching ability training, establishing the mentorship system, information technology application ability training. Novice lecturers are generally satisfied with the implementation of these programs and activities and hope that the university could provide more opportunities to help them grow quickly.
\end{abstract}

Keywords: professional development; practices; activities; novice lecturers

\section{Introduction}

Universities around the world have identified the professional development of lecturers as a key way to improve the conditions of educational institutions and meet the educational challenges of the 21st century (Hardy, 2012). In the higher education field, teaching is an important mission of universities (Zheng, 2017). 
Lecturers, education leaders, and policy makers all play a vital role in higher education activities and should be central to professional development processes (Nguyen, 2019). Novice lecturers are academic staff appointed by higher education institutions for the first time. In the UK and the USA, novice lecturer is equivalent to early-career or new faculty (Brent \& Felder, 2008) and sometimes novice is used in the literature for lecturers who are young and inexperienced. For this study, novice lecturers are those with a master's degree or above and a permanent job in higher education institutions with less than three years of teaching experience.

As enthusiastic educators, novice lecturers need to develop knowledge of teaching content, including the basic elements of the teaching process, to increase the potential of attracting students and improve the quality of teaching (Yu \& Abdullah, 2020). For them, professional development is focused on improving their professional confidence, learning area knowledge, skills, teaching, and classroom management (Steyn, 2011). Their quality level and knowledge reserves will directly affect the teaching work. To grasp the focus of this study, professional development refers to the process of novice lecturers in their careers to improve their teaching skills in various ways.

By the year 2019, young lecturers in China under 35 years old accounted for $28.5 \%$ of the total, and most of them were novice lecturers. They play an important role in university teaching (Zheng, 2017). The Chinese government has recognized the importance of educators in educational development and quality improvement. In 2020, six departments including the Ministry of Education in China issued the Guiding Opinions on Strengthening the Development and Reform of Teaching Staff in Higher Education in the New Era, which emphasized the important position of teaching staff in higher education institutions and stated that universities must build strong lecturer development centers and improve the lecturer development organization system. Therefore, it is necessary to carry out relevant guidelines and policies to help them grow up quickly and improve the quality of teaching (Sumarsono, 2016).

Novice lecturers are adult learners and they may have special needs and requirements. Adult learning theory (Knowles, 1978; Merriam, 2018; Willis, 2021) emphasizes that experience is the most abundant resource for adult learners; they need personalized learning and have learning motivation when learning needs to be met. Scholars such as Knowles (1978) summarized that adult actively learn to meet their own needs in the learning process; adults greatly need self-direction and adult learners need personalized learning. He combined the lifelong learning habits with learning theory. For novice lecturers, professional development policies and programs should take into consideration the achievement outcomes, motivation, instruction, feedback, and efficiency. They already have a certain amount of experience, and they need to connect their learning with previous experience. Moreover, novice lecturers are goaloriented; they know what they want to achieve. Learning has to apply to their work to be valuable to their professional development. The adult learning theory used in this study can explain the experience of novice lecturers in early teaching 
and their perceptions in professional development practices, and clarify the importance of policies and programs for the transition of novice lecturers.

\section{Literature Review}

\subsection{Overview of Professional Development}

Professional development as a concept in occupation has been used in many contexts and there are multiple conceptualizations that different scholars use to refer to professional development. Weir (2017) regards professional development as a lifelong learning process. One of the hallmarks of professionals is continuous learning throughout their careers (Weir, 2017). Wasserman and Migdal (2019) refer to professional development like education and training. Moreover, they point out that training is a learning activity that focuses on acquiring skills and knowledge for their duties. Caena (2011) states that, in addition to initial teacher training, professional development is also related to various activities, which can improve personal knowledge, skills, and abilities. Similar to Caena's view, Day (2002) believes that professional development requires regular and planned-to-learn activities. These activities enable to enhance personal value and promote organizational development.

Evans (2014) makes a different point. He believes that professional development is closely related to personal attitude, behavior, and intelligence. Attitude is the true inner view of personal professional development. Behavior is a concrete manifestation of promoting professional development and intelligence is personal learning ability and reflection ability. In this study, it can be considered that professional development refers to novice lecturers acquiring new knowledge and teaching skills through training to enhance their ability, which may take different approaches.

The emphasis over recent years in research on lecturer professional development has shifted more in the direction of forms of professional development that are multi-faceted (Harris \& Jones, 2019). Lecturer professional development is now regarded as a continuous process that begins during pre-service lecturer training and continues throughout an academic career (Harris \& Jones, 2019). It is an ongoing process whereby lecturers acquire new subject knowledge and teaching method skills (Hallinger \& Liu, 2016).

\subsection{Challenges Faced by Novice Lecturers}

The problems and difficulties that novice lecturers faced in the beginning stage of work usually make them confused (Jeannin \& Hallinger, 2018; Kim \& Roth, 2011). Facing a large number of students, they need to stay focused for the next few hours (Wang, 2011). They often encounter shocks in the first years of teaching when they realize that the principles they have learned before may not be conducive to the real class (Wang, 2011). Tlali (2018) took the National University of Lesotho as a case. Through interviews with several lecturers at the university, he found that there are many challenges in the professional development of lecturers, such as lack of recognition, lack of resources, lack of human resources, delay in policy approval and implementation, and poor attendance of courses. Jeannin and Hallinger (2018) believe that, for 
inexperienced lecturers, teaching in different classes will make them feel uncomfortable because they do not understand students' expectations and learning styles. They may all be unprepared for a variety of learning needs and preferences in the classroom (Jeannin \& Hallinger, 2018). Ibrahim et al. (2013) believe that, although novice lecturers have certain content knowledge, they still lack teaching skills, especially in the first years of work, because the first few years' experiences lay the foundation for their professional development and career planning.

In China, most of these novice lecturers have just graduated from university and are full of curiosity and fantasies about the profession of lecturers (Zheng, 2017). Shi (2015) states that the most common challenge of novice lecturers is that they are difficult to adapt to new roles quickly, such as pressure on work and life, slow transition from student role to educator role, lack of education and teaching experience, and insufficient practical ability. They experience difficulties in adapting to the university culture, either due to the lack of support of relevant training or by teaching subjects that they did not receive training for (Ulvik et al., 2009). Boyd and Lawley (2009) explain that, as a newcomer, novice lecturers need to adapt to many changes, such as new colleagues, new processes, new skills, and most importantly, how to adapt to the current work. Besides, some novice lecturers have never received systematic teacher education; they have limited experience in teaching practice (Shi, 2015). The limitation of teaching strategies and wisdom will make them puzzled. Good teaching requires a variety of skills and traits. These skills need to be improved by participating in various practical activities for training and learning.

\subsection{Professional Development Policies and Practices of Novice Lecturers}

Various countries in the world adopt different policies to ensure the professional development of educators (Ajani, 2021). The development of professional standards frameworks became a trend first in the UK. Different universities have different policies toward the professional development of their lecturers, but they are all aimed at helping them. At Oxford University, there is a program called Preparation for Learning and Teaching Program which consists of half or full-day seminars and deals with practical teaching within a subject. This is a prerequisite for teaching in collegiate discipline groups (Fredericks, 2017). For novice lecturers at the University of Roehampton, the university provides a program called the University of Roehampton Certificate in Learning and Teaching in Higher Education. This course is for newly appointed early-career academics and particular focus is on teaching, learning, and action research. The program also includes observation of teaching by student consultants (Turner et al., 2013). In Australia, the University of Melbourne prepares an Induction Training Program for novice lecturers. They need to attend an online induction training course, where they can conduct group teaching and assistance in a laboratory environment. They are also recommended to participate in induction training provided by the faculties and graduate schools to prepare for a particular disciplinary setting (Hicks et al., 2010). The Young Lecturer Development Program of Peking University in China is also a good reference (PKU, 2016). The purpose of the program is to organize training and research 
activities on pedagogy for novice young lecturers. This program will be implemented every year, and novice young lecturers can complete the credits within three years. This program includes four modules with a total of 96 credits.

\section{Research Purpose}

Current studies on novice lecturer professional development only reveal the socialization process of novice lecturers and lacked an understanding of the needs among novice lecturers (Yu \& Abdullah, 2020; Sumarsono, 2016). This topic is crucial since it contributes to encouraging university leaders to design suitable programs for professional development for novice lecturers. In addition, for novice lecturers, the findings could help them understand the importance of professional development policies and practices, especially their contribution to improving individual capabilities. They could actively participate in professional development programs and activities organized by the university according to their actual situation, thereby promoting professional development. At the institution level, the findings may enable the university management to rethink and revise some aspects of the existing organizing and managing the professional development after considering novice lecturers' perspectives on training and capability development.

Therefore, based on the above, the main purpose of this study is to explore the practice of professional development from the perspective of novice lecturers at a public university in China. Thus, the main questions guiding this study are what are the feelings and experiences of novice lecturers as they participate during the professional development practices?

\section{Methodology}

This study chose to conduct a qualitative case study because it allows researchers to focus on the meaning that participants give to the phenomenon under investigation (Marshall \& Rossman, 2014; Merriam \& Tisdell, 2015). Merriam and Tisdell (2015) state that qualitative research is to understand how people interpret their experiences, how they construct their worlds, and what meaning they attribute to their experiences. The suitability of a qualitative method is further underscored by the aim of this study which seeks to explore the feelings of professional development practices among novice lecturers at the selected public university. The case can be a set of individuals bounded in time and place (Yin, 2017). A case study research design (Yin, 2017) was used in this study as an approach to finding out the practices of professional development in the selected university. In this holistic single case study, the researcher selected a university to explore the feelings and experiences of novice lecturers which could provide a detailed understanding of this specific topic. In this section, sample selection, data collection methods, and data analysis were discussed.

\subsection{Sample Selection}

This study was conducted at University STN, which is a public university in Guangxi Province of China. The reason for choosing this university is that novice lecturers in Chinese public universities could have more development 
opportunities. Another reason is that this university is a newly-built undergraduate university focusing on teaching. Therefore, selecting this university will make this study more meaningful. In a qualitative study, the size of the sample within a case is relevant to the purpose of the study, and the main factor is not the number of participants, but the ability of each participant to contribute to the development of insight and understanding of the study (Merriam \& Tisdell, 2015). Therefore, this study used purposive sampling to select a tentative number of participants from the university. Purposive sampling is a method whereby the researcher subjectively chooses who to include in the research based on their experience and ability to provide necessary data (Merriam \& Tisdell, 2015). Thus, five novice lecturers from different faculties were selected and assigned pseudonyms, Ming, Wei, Song, Kong, and Wang, instead of their real names. All of them have less than three years of teaching experience in higher education institutions. Moreover, their fields are different (Table 1).

Table 1: Background information of participants

\begin{tabular}{|c|c|c|c|c|c|}
\hline Name & Ming & Kong & Wang & Wei & Song \\
\hline Age & 28 & 28 & 27 & 32 & 30 \\
\hline Research field & $\begin{array}{c}\text { Preschool } \\
\text { Education }\end{array}$ & $\begin{array}{c}\text { Marxist } \\
\text { Philosophy }\end{array}$ & $\begin{array}{c}\text { Chinese } \\
\text { Linguistic } \\
\text { Literature }\end{array}$ & Biology & Accounting \\
\hline $\begin{array}{c}\text { Teaching } \\
\text { experience }\end{array}$ & 2 years & 1.5 years & 2 years & 1 year & 3 years \\
\hline $\begin{array}{c}\text { Academic } \\
\text { qualification }\end{array}$ & Master & Master & Master & PhD. & Master \\
\hline
\end{tabular}

\subsection{Data Collection Methods}

In a qualitative study, the researcher, as the main research tool, plays an important role in the research process (Marshall \& Rossman, 2014; Merriam \& Tisdell, 2015). Thus, the researcher collected the data through documentation and semi-structured interviews. As the main source of data, documents in this study are the policies and plans related to professional development, as well as news report on the participation of novice lecturers in various activities. Policies and plans are the rules formulated by leaders to promote the professional development of novice lecturers. The news report about the participation of novice lecturers is the proof and evidence of their professional development. Another method of data collection is semi-structured interviews. The interview questions developed by the researcher are based on the literature (Nguyen, 2019) and research questions. The duration of each participant interview is 60 to 80 minutes. Through interviews, the researcher could understand the current situation of novice lecturers and their true feelings about professional development practices.

\subsection{Data Analysis}

According to Alhojailan (2012), qualitative research requires understanding and collecting different aspects and data. As proposed by Clarke and Braun (2013), 
thematic analysis provides researchers flexibility with the type of research questions; the type of data, such as in-depth interviews, documents and focus group discussions; the volume of data, and so on. Hence, thematic analysis were used in the study to analyse data, which is a qualitative analytic method for identifying, analysing, and reporting themes within data (Braun \& Clarke, 2006; Kiger \& Varpio, 2020).

Thematic analysis includes many steps. After the interview, the recorded materials and documents were organized and transcribed into computer files. Next, the researcher listened to the interviews several times while transcribing the recordings of each participant. After that, the researcher read all transcripts and reviewed the entire record of the recorded interview to verify and match the true expression of the respondents. After doing the above, coding was performed. When coding the data, the researcher carefully read the entire transcripts repeatedly. Similar data, although expressed in different words, was coded similarly and then grouped. Then, the researcher used codes to mark important pieces of information related to the research purposes and questions. After analysing the transcript many times, the themes were established through units of information consisting of phrases, sentences, and segments of the text. The researcher determined some broad themes based on these information units first, then reviewed the transcription and analyzed the data to make specific themes more obvious. These specific themes are relevant to this study. To enhance the trustworthiness, peer review and member checks will be used to make this study more credible. The researcher discussed all aspects of this study with professors or colleagues and asked them to comment. The transcripts were sent to participants so that they could verify the contents and give feedback.

\section{Findings}

In this selected university, all programs and activities related to the professional development of novice lecturers are organized and managed by the Academic Affairs Office and the Human Resources Office. In March 2019, the university issued the Young Lecturers' Teaching Capacity Enhancement Plan, which provides support and assistance to novice young lecturers through teaching competition, teaching ability training, establishing a mentorship system, and improving information technology application ability.

\subsection{Teaching Competition}

Teaching competition is an important activity to show the teaching ability and skills of novice lecturers. The purpose of the teaching competition is to promote interaction and communication between novice lecturers, which helps to create a good atmosphere for teaching in the whole university. The competition is organized by the Academic Affairs Office once or twice a year. A faculty-level competition will be held by each faculty, and then outstanding lecturers will be selected to participate in the final held by the university. Novice lecturers who perform well in the finals will be commended and recommended for higherlevel competitions. 
The competition consists of three parts. The first part is teaching design, which accounts for $20 \%$. Teaching design refers to the assumption and arrangement of teaching activities. It mainly includes course name, teaching objective, teaching idea, course resources, teaching content, teaching key and difficult points, teaching methods and tools, teaching arrangement, teaching evaluation, preview task, and assignments. Lecturers have to prepare the teaching design of the course, which will then be graded by the judges. The second part is classroom teaching, accounting for $75 \%$. Lecturers extract lecture sections in advance and then conduct a 20-minute lecture. The judges evaluate the teaching content, teaching organization, teaching language, teaching style, and teaching characteristics. Lecturers need to prepare the slides of the courses, and the classroom teaching content should be consistent with the teaching design content submitted. The third part is teaching reflection. After the end of the classroom teaching, lecturers combine with the classroom teaching practice of this section, from the aspects of teaching philosophy, teaching methods, and teaching process, in the 3-5 minutes given to reflect and make a statement to the judges; this part accounts for 5\%. Finally, the lecturer's total score is based on the combination of three parts.

Through interviews, Ming and Song, two novice lecturers who have participated in the competition, state their views:

"The teaching competition for me is like a double-edged sword. It gives me pressure, but it also encourages me. Through the competition, I could find my shortcomings and learn the advantages of other excellent lecturers." (Ming)

"I won a good place in last year's competition, which builds confidence. The competition is a platform for lecturers to communicate and learn from each other." (Song)

Ming and Song both believed that participating in the teaching competition helped them. They regard competition as an effective way to evaluate their professional development. Through the comments of the judges, they can improve and make themselves more experienced. This is a process of continuous reflection and continuous improvement (Geng \& Yu, 2021; Shu, 2012). The other three lecturers have not participated in the competition, but they all support this activity.

"I missed this year's competition, but I am ready for next year." (Kong)

"The competition is very attractive to me; it can help me adapt to teaching as soon as possible." (Wei)

"Although it is a form of competition, its purpose is to help novice lecturers to develop their professional skills. I didn't participate this year because I was not confident enough." (Wang)

Based on a clear understanding, these three lecturers have not yet participated in the teaching competition. They know their current shortcomings, but they all say they will participate once they are ready. In addition, through the news report 
related to the teaching competition for novice lecturers held by the university, it can be seen that the teaching competition could arouse the enthusiasm of novice lecturers and the participation of lecturers is very high.

\subsection{Teaching Ability Training}

The purpose of teaching ability training is to help novice lecturers master the preparation requirements of teaching plans, syllabus, and teaching design. The ways of teaching ability training include workshops, seminars, classroom observation, and so on. Novice lecturers need to grasp the course positioning, correctly analyze and process the teaching materials, and complete the teaching design with high quality. In addition, they must be proficient in the basic skills and teaching methods of classroom teaching and conduct evaluation and reflection.

At the university level, the Office of Academic Affairs organizes three to four workshops and seminars every year. The topics of these workshops and seminars are pedagogy, teaching research, teaching plan writing, teaching organization, and management. Because the university is a normal university that focuses on undergraduate teaching, teacher educators must understand all of these to teach students more effectively. At the faculty level, each lecturer is obliged to observe at least six other lessons every semester. The contents of the observation are mainly the lecturer's preparation, teaching plans, use of multimedia courseware, teaching content, teaching methods, and teaching attitude. Observation notes are written in a notebook that needs to be submitted at the end of each semester, which will be archived and managed by the faculty. Teaching ability training is a basic activity to enhance professional development and every novice lecturer needs to participate.

"I always participate in these workshops and seminars organized by the Office of Academic Affairs. The professors who instruct us are all experienced professors in the field." (Kong)

"My field is biology. I lack knowledge of pedagogy and educational psychology; it was quite stressful when I first started teaching. However, as long as there is a pedagogical workshop, I will participate. This helps me." (Wei)

"I hope that the university invites more professors to instruct us because workshops could really help me." (Ming)

Kong, Song, and Ming share the same views on workshops and seminars. Both the workshop and the seminar provided help for their professional development. The interactive part of the workshop can give them a real sense of experience, which is the driving force for their progress (Cai et al., 2020). Regarding classroom observation, lecturers have different views.

"To be frank, I feel that classroom observation is not very useful. Every time our notebook is submitted to the faculty, there is no feedback. This is a problem." (Wei) 
"I think the significance of classroom observation lies in evaluating the lecturer, although I can learn from some experienced lecturers through classroom observation." (Wang)

"It can't be said that classroom observation is not good, it is helpful. But I think it is not as helpful as workshop and seminar." (Song)

"This is a prescribed task; I can only say that I will complete it." (Kong)

As you can see from what the four lecturers said, they took a neutral attitude toward classroom observation, which was not fully affirmed like seminar and workshop. They don't think classroom observation is effective enough to help their professional development, but they still stick with it.

\subsection{Mentorship}

University STN strongly encourages the implementation of the mentorship system, the purpose of which is to help novice lecturers familiarize themselves with the work as soon as possible and further improve the level of teaching and scientific research. Every year, the university will issue a notification that associate professors or above can voluntarily sign up to mentor novice lecturers. The content of the mentoring includes teaching preparation, writing teaching plans, lectures, and evaluation. In addition, associate professors or above must also mentor or cooperate with the novice in applying for scientific research projects, and guide to write and publish more than one academic or teaching research paper. Novice lecturers can ask their mentors about teaching plans, academic and teaching questions. These five novice lecturers are all being mentored.

"My mentor is a very patient professor, and every time I communicate with him, I get all inspirations. He declared a project this year, and I joined in as a member." (Ming)

"I don't have much communication with my mentor, but whenever I asked her questions about teaching, she could answer them one by one. For example, she told me to treat my students as friends so I wouldn't feel anxious." (Kong)

"My mentor often listens to my lecture in the classroom and gives me feedback, then tells me my weaknesses and shortcomings for improvement. He also guided me on how to apply for the project." (Wang)

"I know that I am inexperienced in teaching, so I take the initiative to communicate with my mentor, and often listen to his lectures. Besides, I often invite him to listen to my lectures and give me opinions." (Wei)

"I think this mentoring is not very helpful to me. My mentor hardly guides me because of her busy work. She sometimes asks me to help her with trivial things, such as downloading papers." (Song) 
From the experience of the above five novice lecturers, it is not difficult to see that the effectiveness of mentoring is inseparable from the interaction between novice lecturers and their mentors. Active mentors can give lecturers a full range of guidance and help them grow in a real sense. Some mentors are only nominal and do not guide the professional development of novice lecturers. Mentoring is an important approach to help novice employees grow quickly, and it is also widely used in other fields, such as doctors and technicians (Ramhurry, 2013). However, how to make full use of the advantages of mentoring needs to be further explored.

\subsection{Information Technology Application Ability Improvement Training}

The training of information technology applications aims to improve the ability of novice lecturers to acquire, communicate, process, and apply teaching information through the use of information technology. The training content includes multimedia courseware, micro-lectures, MOOC, etc. The training of information technology application ability focuses on the development of novice lecturers' information teaching ability. After each training session, each lecturer needs to submit excellent courseware or micro-class. The Academic Affairs Office will evaluate the participating lecturers. Those who fail the assessment will continue to participate in the next training session. The assessment results are filed by the Human Resources Office, the Academic Affairs Office, and the faculty, as one of the references for professional qualification recognition and job appointment of novice lecturers. Their views on this training are as follows.

"My students are normal students and they will work in kindergartens in the future. The ability to information technology applications is important for normal students. So, I have the responsibility to improve myself to better teach them." (Ming)

"I was very good at this when I was a student, so there is no challenge for me now. I will actively participate in the training organized by the university." (Kong)

"The training in information technology application is very helpful to me. I was not good at these at first, but after training, I can do better in this area." (Wang)

"I think the application of information technology is a necessary skill for university lecturers. The university organizes training to promote our skills, so I do participate." (Wei)

"I like this training very much. The application of information technology can be said to be my strong point and I also won a prize in the MOOC competition held in the province last year." (Song)

These five lecturers are all in favor of the training of information technology applications, and they are all willing to participate. The application of information technology in education adapts to the current trend of the times and can lay a good foundation for the work of lecturers. The use of information technology in education can help improve teaching efficiency and promote 
interaction between lecturers and students (Hbaci et al., 2021). Because modern educational technologies such as micro-lectures and MOOCs (Khalid et al., 2021; Wang et al., 2020) can display not only text, pictures, but also video and sound, and can be connected to the internet, they can make teaching content more vivid and interesting, and make it easier for students to understand (Wang et al., 2020).

\section{Conclusion}

Based on the above findings, it can be concluded that the professional development practices of novice lecturers in this selected university mainly include teaching competitions, teaching ability training, mentoring, and information technology application ability training. Novice lecturers support these activities and believe that these programs and activities have provided help to their professional development. The teaching competition is a demonstration of the teaching effect of lecturers. It can not only inspire lecturers to devote more enthusiasm to teaching, but also improve their abilities by learning from excellent lecturers. Workshops and seminars in the teaching ability training are also important ways to help novice lecturers clarify the teaching tasks and improve their teaching skills. However, lecturers generally think that classroom observation, which is also one of the teaching ability trainings, is not very helpful. The consequences resulting from mentorship are determined by the relationship between the mentor and the novice lecturer. However, most lecturers still affirm the help of mentoring. The application of information technology is an indispensable skill for university lecturers, and enhancing training in this area is of great benefit to novice lecturers.

\section{Suggestions}

This study explores the professional development practices of novice lecturers at a selected public university in China, which not only enriches the theoretical knowledge on the development of novice lecturers' professional development but also has practical significance for the management of the novice lecturers in universities. For theoretical, this study highlights some relevant professional development concepts from the perspective of novice lecturers, the application of adult learning theory indicates that professional development is a long process. For practical, this study is relevant to the management of universities. Professional development of novice lecturers cannot be conducted without planning. To achieve the goal of novice lecturer professional development, universities need to encourage the deans of faculties, heads of units, and experts in the universities to participate in the process. At the same time, the university management should pay attention to the novice lecturers' views on professional development activities, and consider their feedback in the improvement of relevant policies and training, to formulate plans that meet the characteristics of novice lecturers and are beneficial to their development.

\section{Limitations and Future Work}

In addition, this study has a potential weakness or limitations. Firstly, the researcher purposively sampled participants from one public university in China. Given the relatively small size of participants, the findings would be 
unique to themselves. Due to the large number of novice lecturers in universities, there must be more individualized problems. This means the policies in the university and the characteristics of those participants in this study are specific, so the findings might not be employed beyond the given settings. Therefore, the author hopes that future researchers may use other research designs, for example, use narrative to explore the lived experience of novice lecturers or use quantitative research to investigate the relationship between leadership practice and lecturer professional development.

\section{Acknowledgements}

The author would like to thank all the participants in this study as well as the selected university.

\section{References}

Ajani, O. A. (2021). Teachers' perspectives on professional development in South Africa and Nigeria: Towards an andragogical approach. Journal of Educational and Social Research, 11(3), 288-300. https://doi.org/10.36941/jesr-2021-0070

Alhojailan, M. I. (2012). Thematic analysis: A critical review of its process and evaluation. West East Journal of Social Sciences, 1(1), 39-47.

Boyd, P., \& Lawley, L. (2009). Becoming a lecturer in nurse education: the work-place learning of clinical experts as newcomers. Learning in Health and Social Care, 8(4), 292-300. https://doi.org/10.1111/j.1473-6861.2009.00214.x

Braun, V., \& Clarke, V. (2006). Using thematic analysis in psychology. Qualitative Research in Psychology, 3(2), 77-101.

Brent, R., \& Felder, R. M. (2008). A professional development program for graduate students at North Carolina State University. Proceedings of the 2008 ASEE Annual Conference (pp. 1-10), Pittsburgh, PA.

Caena, F. (2011). Literature review quality in teachers' continuing professional development. European Commission, 2-20.

Cai, J., Chen, T., Li, X., Xu, R., Zhang, S., Hu, Y., Zhang, L., \& Song, N. (2020). Exploring the impact of a problem-posing workshop on elementary school mathematics teachers' conceptions on problem posing and lesson design. International Journal of Educational Research, 102, 1-20. https:/ / doi.org/10.1016/j.ijer.2019.02.004

Clarke, V., \& Braun, V. (2013). Teaching thematic analysis: Overcoming challenges and developing strategies for effective learning. The Psychologist, 26(2).

Day, C. (2002). Developing teachers: The challenges of lifelong learning. Routledge.

Evans, L. (2014). Leadership for professional development and learning: enhancing our understanding of how teachers develop. Cambridge Journal of Education, 44(2), 179-198. https:// doi.org/10.1080/0305764X.2013.860083

Fredericks, S. P. K. (2017). Advancing scholarship of teaching and learning during professional development of new lecturers at higher education institutions. [Doctoral thesis, NorthWest University]. http:// repository.nwu.ac.za/handle/10394/25101

Geng, F., \& Yu, S. L. (2021). EFL teachers' classroom assessment literacy and practice A text analysis of lesson plans in a national college English teaching contest. Foreign Language Teaching and Research, 53(2), 238-250.

Hallinger, P., \& Liu, S. (2016). Leadership and teacher learning in urban and rural schools in China: Meeting the dual challenges of equity and effectiveness. International Journal of Educational Development, 51, 163-173. https://doi.org/10.1016/j.ijedudev.2016.10.001 
Hardy, I. (2012). The politics of teacher professional development: Policy, research, and practice. Routledge.

Harris, A., \& Jones, M. (2019). Leading professional learning with impact. School Leadership $\mathcal{E} \quad$ Management, $39(1), \quad$ 1-4, http://doi.org/10.1080/13632434.2018.1530892

Hbaci, I., Ku, H. Y., \& Abdunabi, R. (2021). Evaluating higher education educators' computer technology competencies in Libya. Journal of Computing in Higher Education, 33(1), 188-205. https://doi.org/10.1007/s12528-020-09261-z

Hicks, M., Smigiel, H., Wilson, G., \& Luzeckyj, A. (2010). Preparing academics to teach in higher education: Final report. Australian Learning and Teaching Council. https://core.ac.uk/download/pdf/81291121.pdf

Ibrahim, A. B., Mohamad, F., Rom, K. B. M., \& Shahrom, S. M. (2013). Identifying strategies adopted by novice lecturers in the initial years of teaching. ProcediaSocial and Behavioral Sciences, 90, 3-12. https://doi.org/10.1016/j.sbspro.2013.07.059

Jeannin, L., \& Hallinger, P. (2018). Exploring the need to contextualize professional development programs for university lecturers: A case study in Thailand. The Independent Journal of Teaching and Learning, 13(2), 98-112.

Khalid, B., Chaveesuk, S., \& Chaiyasoonthorn, W. (2021). MOOCs Adoption in Higher education: A management perspective. Polish Journal of Management Studies, 23(1), 239-256. https://doi.org/10.17512/pjms.2021.23.1.15

Kiger, M. E., \& Varpio, L. (2020). Thematic analysis of qualitative data: AMEE Guide No. 131. Medical Teacher, 42(8), 846-854. https://doi.org/10.1080/0142159X.2020.1755030

Kim, K. A., \& Roth, G. L. (2011). Novice teachers and their acquisition of work-related information. Current Issues in Education, 14(1), 1-28.

Knowles, M. S. (1978). Andragogy: Adult learning theory in perspective. Community College Review, 5(3), 9-20. https:// doi.org/10.1177/009155217800500302

Marshall, C., \& Rossman, G. B. (2014). Designing qualitative research. (6th ed.). Sage Publications.

Merriam, S. B. (2018). Adult learning theory: Evolution and future directions. In K. Illeris (Ed.), Contemporary Theories of Learning. Routledge.

Merriam, S. B., \& Tisdell, E. J. (2015). Qualitative research: A guide to design and implementation (4th ed.). John Wiley \& Sons.

Nguyen, H. C. (2019). An investigation of professional development among educational policy-makers, institutional leaders and teachers. Management in Education, 33(1), 32-36. https:// doi.org/10.1177/0892020618781678

Peking University (2016). Young Lecturer Teaching Development Program. Peking University. http://cetl.pku.edu.cn/peking/tal/view1/to/toxiangmu.jsp

Ramhurry, R. (2013). How Mentorship Practices at a University in Johannesburg Contributes to the Social Learning of Novice Lecturers [Master's thesis, University of Johannesburg]. http://hdl.handle.net/10210/8838

Rowe, K. (2003). The importance of teacher quality as a key determinant of students' experiences and outcomes of schooling. Proceedings of ACER Research Conference 2003. (pp. 15-23). https://research.acer.edu.au/research_conference_2003/3

Shi, H. (2015). Research on the current situation of young lecturers' professional development in local university [Master's thesis, Yangzhou University]. https://kns.cnki.net/KCMS/detail/detail.aspx?dbname=CMFD201602\&filena $\mathrm{me}=1015662332 . \mathrm{nh}$ 
Shu, D. F. (2012). The SFLEP National College English Teaching Contest and teacher development. Foreign Language World, 3, 34-41. https://en.cnki.com.cn/Article_en/CJFDTotal-WYJY201203007.htm

Steyn, T. (2011). Implementing continuing professional teacher development: policy and practice. Acta Academica, 43(1), 211-233.

Sumarsono, P. (2016). Professional development for novice EFL lecturers: Policy and practices at University of Muhammadiyah Malang. Proceedings of the International Conference on Teacher Training and Education 2015, (pp. 780-787). https://core.ac.uk/download/pdf/289793268.pdf

Tlali, T. (2018). Continuing professional development for lecturers at the National University of Lesotho: Milestones and challenges. International Journal of African Higher Education, 5(1), 107-121. https://doi.org/10.6017/ijahe.v5i1.10966

Turner, N., Oliver, M., McKenna, C., Hughes, J., Smith, H., Deepwell, F., \& Shrives, L. (2013). Measuring the impact of the UK Professional Standards Framework for Teaching and Supporting Learning (UKPSF). https://www.heacademy.ac.uk/system/files/resources/UKPSF_Impact_Study Report.pdf

Ulvik, M., Smith, K., \& Helleve, I. (2009). Novice in secondary school-the coin has two sides. Teaching and Teacher Education, 25(6), 835-842. https://doi.org/10.1016/j.tate.2009.01.003

Wang, H. (2011). Cocoon butterfly: Narrative research of three new teachers' professional development in high college [Master's thesis. Northeast Normal University]. https://kns.cnki.net/KCMS/detail/detail.aspx?dbname=CMFD2012\&filename $=1012294448 . \mathrm{nh}$

Wang, K., Zhu, C., \& Tondeur, J. (2020). Using micro-lectures in small private online courses: what do we learn from students' behavioural intentions? Technology, Pedagogy and Education, 30(3), 427-441. https:// doi.org/10.1080/1475939X.2020.1832565

Wasserman, E., \& Migdal, R. (2019). Professional development: Teachers' attitudes in online and traditional training courses. Online Learning, 23(1), 132-143. https://doi.org/10.24059/olj.v23i1.1299

Weir, C. D. (2017). Understanding self-directed professional development in mathematics for elementary teachers: A phylogeographical study [Doctoral thesis, The University of Western Ontario]. https://ir.lib.uwo.ca/etd/5110

Willis, K. L. (2021). Adult Learning Theory: Reflections on the role of mentoring as a key to success in advanced degree programs. American Journal of Educational Research and Reviews, 6, 80.

Yin, R. K. (2017). Case study research and applications: Design and methods (6th ed.). Sage Publications.

Yu, H., \& Abdullah, A. (2020). Exploring the Process of Occupational Adaptation among Novice Lecturers: A Preliminary Case Study. Universal Journal of Educational Research, 8(12B), 8369-8375. http:// doi.org/10.13189/ujer.2020.082642

Zheng, Y. T. (2017). Study on problems, influence factors, and countermeasures presenting in professional development of the beginning college teachers - Taking Yunnan Normal University as an example [Master thesis, Yunnan Normal University]. https://kns.cnki.net/KCMS/detail/detail.aspx?dbname=CMFD201801\&filena $\mathrm{me}=1017730312 . \mathrm{nh}$ 


\section{Appendix}

\section{Interview Protocol}

Thank you for accepting to participate in this study. The purpose of this study is to explore the practice of professional development from the perspective of novice lecturers at a public university. During the interview, I want you to talk about your views and experiences of professional development practices. I have some broad questions for you but feel free to talk about anything that you want to about your experience. Thanks.

\begin{tabular}{|l|l|l|l|}
\hline \multicolumn{3}{|c|}{ Background information } \\
\hline Age & Degree/Qualification & \\
\hline Teaching subject & Years of teaching experience & \\
\hline
\end{tabular}

\begin{tabular}{|c|l|}
\hline No. & \multicolumn{1}{|c|}{ Interview questions } \\
\hline 1 & What kind of programs and activities in your university? \\
\hline 2 & $\begin{array}{l}\text { Have you attended the professional development programs or activities? } \\
\text { If yes, tell me some specific actions. } \\
\text { If not, tell me why you didn't attend. }\end{array}$ \\
\hline 3 & $\begin{array}{l}\text { What motivates you to participate in professional development programs } \\
\text { and activities? }\end{array}$ \\
\hline 4 & $\begin{array}{l}\text { Do you feel that participating in programs and activities has improved } \\
\text { your skills as a lecturer? } \\
\text { If so, what new knowledge and skills did you acquire from the training? } \\
\text { If not, why do you think these programs and activities do not promote } \\
\text { your professional development? }\end{array}$ \\
\hline 5 & $\begin{array}{l}\text { Is there any follow-up by the organizer when after participating in the } \\
\text { professional development programs and activities? }\end{array}$ \\
\hline 6 & $\begin{array}{l}\text { What do you suggest should be improved in the implementation of } \\
\text { professional development programs and activities, and why? }\end{array}$ \\
\hline 7 & $\begin{array}{l}\text { In addition to these programs and activities, what other better programs or } \\
\text { activities do you hope the university could provide? }\end{array}$ \\
\hline 8 & $\begin{array}{l}\text { Would you like to share anything other than the question we discussed on } \\
\text { the topic? }\end{array}$ \\
\hline
\end{tabular}

